\title{
Responses of Syrphids, Elaterids and Bees to Single-tree Selection Harvesting in Algonquin Provincial Park, Ontario
}

\author{
Erica Nol ${ }^{1}$, Hume Douglas ${ }^{1,2}$, and William J. CRins ${ }^{3}$ \\ ${ }^{1}$ Biology Department, Trent University, Peterborough, Ontario K9J 7B8 Canada \\ ${ }^{2}$ Present address: Biology Department, Carleton University, 1125 Colonel By Drive, Ottawa, Ontario K1S 5B6 Canada \\ ${ }^{3}$ Planning and Research Section, Ontario Parks, Ontario Ministry of Natural Resources, 300 Water Street, Peterborough, \\ Ontario K9J 8M5 Canada
}

Nol, Erica, Hume Douglas, and William J. Crins. 2006. The response of syrphids, elaterids and bees to single-tree selection
harvesting in Algonquin Provincial Park, Ontario. Canadian Field-Naturalist 120(1): 15-21.

The species composition of hoverflies (Syrphidae), click beetles (Elateridae), and bees (Apoidea) was studied to determine whether there was a positive response in these flower-seeking insect groups to gaps in the canopy created through singletree selection harvesting of Sugar Maple (Acer saccharum) and Yellow Birch (Betula alleghaniensis) in hardwood forests of the Great Lakes-St. Lawrence forest region of Algonquin Provincial Park, Ontario. There were significantly more hoverflies and bees collected in forest stands harvested within the previous five years than in wilderness zone (unharvested at least for 40 years) stands or stands harvested 15-20 years previously (old logged stands). Click beetles, especially Selatosomus pulcher (LeConte), were collected most often in old logged stands. Bees and click beetles were collected significantly later in the season in logged than in wilderness zone stands. Malaise traps resulted in higher capture rates for syrphids than pan traps, and only with these higher capture rates did we detect a significant increase in species richness in recently logged stands over that in wilderness stands. Changes in the numbers and phenology of flower-visiting insects may impact on reproductive success of flowering plants of the forest understory and deserves further study.

Key Words: single-tree selection logging, syrphids, hoverflies, Syrphidae, click beetles, Elateridae, bees, Apoidea, Algonquin Provincial Park, hardwood forests.

Single-tree selection harvesting ${ }^{\dagger}$ in shade-tolerant hardwood forests creates cyclic perforations in the canopy on a 20-25 year rotation and is hypothesized to simulate conditions found under gap-phase dynamics. This form of silviculture is practised in many parts of the Great Lakes-St. Lawrence Forest Region in Ontario and Quebec (Hunter 1990). Very little is known about the impact on non-target species of removing $25 \%$ of the basal area of the forest through selection cutting (Annand and Thompson 1997).

Particular invertebrate groups are most likely to respond to changes in light conditions of the forest floor as a result of reductions in canopy cover. Many plants respond positively to increased light. As a result, insects with adult stages attracted to conspicuous flowers, also are expected to increase in abundance. These include bees (Hymenoptera: Apoidea), hoverflies (Diptera: Syrphidae), a family of flies that contains important flower visitors and pollinators (Waldbauer 1983; Kula 1997; Goulson and Wright 1998; Gross 2001), and many click beetles (Coleoptera: Elateridae), a less well-known group of flower visitors (Johnson 2002).

Changes in other components of the forest as a result of selection cutting may also benefit these insects. Larvae of hoverflies of the subfamily Syrphinae feed largely on aphids (Vockeroth 1992), and may benefit from increased herbaceous growth associated with canopy opening. Larvae of many elaterids (Johnson 2002) and some hoverflies of the subfamily Eristalinae (Vockeroth 1992) inhabit decaying wood. Their response to logging may depend on the availability of amounts, sizes and decay states of the standing and fallen trees remaining after each phase of the logging cycle. Soil-inhabiting elaterid larvae and ground-nesting bees may be affected by changes in vegetation, litter composition and depth, microclimate, and soil disturbance (Penev 1992; Sugar et al. 1998). Disturbance caused by construction of sand logging roads may result in greater colonization by psammophilous bees and elaterids in a previously unsuitable forest stand (Cane 1991).

We studied the impact of selection cutting on these non-target invertebrates in Algonquin Park, Ontario. We predicted positive density responses for all three groups, either as a result of an increase in spring flora, or other changes associated with logging. We also predicted that the presence of insects that visit flowers would extend later into the growing season in logged forests than in unlogged stands because of the greater amount of light penetrating to the forest floor throughout the spring and summer seasons. We tested these predictions by comparing these insect communities in

\footnotetext{
$\dagger$ Under selection harvesting, only some of the trees are cut in order to balance the volume of wood harvested with the amount produced through new growth and to enhance biodiversity and ecological functions. This system of silviculture differs from selective harvesting in which only the best timber trees are cut and the forest is gradually degraded.
} 
stands cut 6 months to 3 years before our sampling, 15-20 years before, and in stands that have not been subjected to logging for at least 40 years.

\section{Study Area and Methods}

The study was conducted in the summers of 1997 and 1998 in Algonquin Provincial Park, Ontario $\left(42^{\circ} 32^{\prime} \mathrm{N}, 78^{\circ} 36^{\prime} \mathrm{W}\right)$, as part of a larger study that was examining impacts of logging on birds (Jobes et al. 2004) and ground beetles (Carabidae: Vance and Nol 2003). Forest stands were chosen randomly (within the constraint that they be within $500 \mathrm{~m}$ of road access) in wilderness designated zones (Algonquin Park Management Plan 2000), last logged at least 40 years prior to survey), old logged (15-20 years post cutting), and recently logged (6 months -3 years post cutting) areas. Canopy cover (estimated in July) ranged from 60$70 \%$ in the wilderness zone to $25-35 \%$ in old cut and recently cut stands, and was significantly higher in the wilderness zone stands than in both the old logged and recently-cut stands (Jobes et al. 2004). Other vegetation differences included a significant increase in vegetation under $2 \mathrm{~m}$ and percent logging residue cover (mostly tops of trees) in the recently cut stands over that in the other two treatments, and a significant increase in stem densities and saplings $(2-5 \mathrm{~m})$ and subcanopy $(5-10 \mathrm{~m})$ vegetation in the old logged treatments as compared to the other two (Jobes et al. 2004).

In 1997, we used a single Malaise trap set on a ridge in one stand of each of the recently logged and wilderness zone treatments. It was emptied at 1-week intervals every other week from May to August. Thus, we had no replication of stands for this year. In 1998, we set yellow pan traps $\left(21 \mathrm{~cm}^{2} \times 5 \mathrm{~cm}\right.$ depth) filled with water to a depth of $2-3 \mathrm{~cm}$, and a small amount of detergent in a total of 18 stands. These traps were set, within stands, at $100 \mathrm{~m}$ intervals at permanent markers. We sampled eight stands in the wilderness zone, seven in the recently logged areas, and three in the old logged areas. Stands were separated by a minimum of $200 \mathrm{~m}$, but most stands were separated by $>3 \mathrm{~km}$, in stands consisting of at least $75 \%$ upland deciduous forest (Vance and Nol 2003) so we assumed that they were spatially independent. Each stand contained a minimum of three traps. The sampling was uneven in the treatments because of accessibility of stands and because two of the initial old logged treatments were logged in the winter of 1997-1998. These traps were set from early May to late August, and emptied weekly for three weeks in early, mid, and late summer periods, for a total of nine trapping weeks. There were 69 incidents of trap disturbance by mammals.

Pitfall traps were used to obtain activity-density estimates for click beetles (Baars 1979). Pitfalls were constructed using 1 litre plastic $11.5 \mathrm{~cm}$ diameter containers lined with $500 \mathrm{~mL}$ plastic containers of the same diameter (Spence and Niemelä 1994). The traps were dug into the ground so that the top of the upper contain- er was level with or slightly below the surface of the soil. Each trap was filled with approximately $300 \mathrm{ml}$ of water, with a few drops of dish soap added to reduce surface tension. Two pitfall traps were set at $4 \mathrm{~m}$ to each side of the permanent stand markers, at the same intervals as the pan traps. In 1997, pitfalls were set for one week in each of May through August for a total of four weeks. In 1998, pitfalls were set for the same periods as the pan traps. A small number of traps (5\%) were disturbed in all treatments

All invertebrates were sorted initially to class, and all but insects were discarded. Insects of the three target groups were then sorted and identified with the use of keys by Becker (1956, 1974); Brown (1934); Coovert and Thompson (1977); Curran (1921, 1922, 1925, 1934, 1941); Curran and Fluke (1926); Dietrich (1945); Fluke and Hull (1945); Fluke and Weems (1956); Hull and Fluke (1950); Michener et al. 1994; Mitchell (1960); Shannon (1939); Telford (1970); Vockeroth and Thompson (1981); and Vockeroth (1992). Voucher specimens are deposited in the Canadian National Collection of Insects and Arthropods, Agriculture and Agri-food Canada, Ottawa.

As we began sampling in all treatments at the same time, we used the dates (1998 only) on which the target groups were captured as independent samples, for our comparisons of phenology. These data were highly skewed so we used the Kruskal-Wallis ANOVA to test for significance among treatments. We were unable to use stands as sampling units for any statistical comparisons because capture rates were too low. Thus, we tested for significant differences among treatments in species and numbers of individuals trapped, using chisquare tests, with proportion of total trapping effort among treatments used to calculate expected numbers. We report standardized residuals ((Observed Expected) $/ \sqrt{ }$ Expected) and their direction to show which treatment had greater or less than the numbers of individuals or species than expected based on our sampling effort (Quinn and Keough 2002). For pitfalls and pan traps we usually caught single individuals of the target species and these were spread across a range of stands within that treatment, so that the assumption of independence for this statistical test was probably not violated (i.e., the samples are not biased by many individuals caught in one particular stand and treatment except in cases where noted below). Given the low capture rate for any of our target groups we did not calculate or analyse patterns of diversity.

To assess spring ephemeral abundance, we counted, in $1 \mathrm{~m}^{2}$ quadrats placed $5 \mathrm{~m}$ to the side of pitfall and pan trap locations, all visible stems of spring-blooming forb species during the first sampling period in May 1998, before canopy leaf emergence.

\section{Results}

Each of the three target groups had substantially higher captures per unit effort (combining sample across all stands per treatment because of low num- 
bers captured) in at least one logged treatment than in the wilderness zone treatment (Table 1).

Syrphids. In both years, with both pan and malaise trapping methods, more species of syrphids were caught in logged than in unlogged landscapes (Table 2). In 1997, eight species were found in wilderness zone malaise traps and 25 species were trapped from the recently logged stands with three species in common between the two treatments. As Malaise traps were opened for an equal number of days in the two stands, we calculated expected numbers using the binomial distribution, based on $P=0.5$. Significantly more
TABLE 1. Catch per unit effort $(\times 100)$ for all Syrphidae, Elateridae and Apoidea caught in pan traps in recently logged, old logged, and wilderness stands in 1998, and combined catch for pitfalls in 1997 and 1998.

\begin{tabular}{lccc}
\hline \hline & $\begin{array}{c}\text { Recently } \\
\text { Logged }\end{array}$ & $\begin{array}{c}\text { Old } \\
\text { Logged }\end{array}$ & Wilderness \\
\hline Total pan trap days & 1894 & 1040 & 2961 \\
Total pitfall days & 4796 & 3088 & 7938 \\
Syrphidae (pan) & 0.68 & 2.31 & 0.17 \\
Elateridae (pan) & 1.37 & 6.82 & 3.71 \\
Elateridae (pitfall) & 0.27 & 1.49 & 0.30 \\
Apoidea (pan) & 3.22 & 2.11 & 1.28 \\
\hline \hline
\end{tabular}

TABLE 2. Species and numbers of individuals captured of Syrphidae from pan traps set in recently logged, old logged, and wilderness stands in Algonquin Provincial Park using Malaise traps in 1997 and pan traps in 1998. $\chi^{2}$ statistic provided for test of association between number of individuals and species and logging treatment. Standardized residuals give direction and strength of deviation (Quinn and Keough 2002)

\begin{tabular}{|c|c|c|c|c|c|}
\hline \multirow{2}{*}{$\begin{array}{l}\text { Species } \\
\text { Year }\end{array}$} & \multicolumn{2}{|c|}{ Wilderness } & \multirow{2}{*}{$\frac{\text { Old logged }}{1998}$} & \multicolumn{2}{|c|}{ Recently logged } \\
\hline & 1997 & 1998 & & 1997 & 1998 \\
\hline \multicolumn{6}{|l|}{ Sub-Family Syrphinae } \\
\hline Baccha elongata (Fabricius) & 1 & 1 & & & \\
\hline Dasysyrphus pauxillus (Williston) & 2 & & & & \\
\hline Epistrophe nitidicollis (Meigen) & & & & 1 & \\
\hline Eupeodes perplexus (Osburn) & & 1 & & 3 & \\
\hline Eupeodes americanus (Wiedemann) or pomus (Curran) & & & & 1 & \\
\hline Melanostoma mellinum (Linnaeus) & & 2 & 23 & 9 & 4 \\
\hline Meliscaeva cinctella (Zetterstedt) & & & & 1 & \\
\hline Parasyrphus semiinterruptus (Fluke) & & & & & 2 \\
\hline Parasyrphus sp. & 1 & & & & \\
\hline Platycheirus confusus (Curran) & 1 & & & 3 & \\
\hline Platycheirus obscurus (Say) & & & & 10 & \\
\hline Sphaerophoria novaeangliae (Johnson) & & & & 10 & \\
\hline Syrphus rectus (Osten Sacken) & & & & 1 & \\
\hline Toxomerus geminatus (Say) & 1 & & & 2 & \\
\hline \multicolumn{6}{|l|}{ Sub-Family Eristalinae } \\
\hline Brachyopa notata (Osten Sacken) & & & & 1 & \\
\hline Brachypalpus oarus (Walker) & & & & 1 & \\
\hline Chalcosyrphus nemorum (Fabricius) & & 1 & & 4 & 2 \\
\hline Cheilosia rita (Curran) & & & & 1 & \\
\hline Cheilosia tristis (Loew) & & & & 1 & \\
\hline Eristalis dimidiatus (Wiedemann) & & & & 1 & \\
\hline Helophilus fasciatus (Walker) & & & & & 1 \\
\hline Lejota aerea (Loew) & & & & 1 & \\
\hline Lejota cyanea (Smith) & & & & 3 & \\
\hline \multicolumn{6}{|l|}{ Neoascia distincta (Williston) } \\
\hline Pipiza femoralis (Loew) & & & & & 1 \\
\hline Rhingia nasica (Say) & 2 & & 1 & 4 & \\
\hline Sericomyia chrysotoxoides (Macquart) & & & & 1 & 1 \\
\hline Sphegina brachygaster (Hull) & & & & & 1 \\
\hline Sphegina flavomaculata (Malloch) & 1 & & & & \\
\hline Sphegina keeniana (Williston) & & & & 2 & \\
\hline Sphegina campanulata (Robertson) & & & & 2 & \\
\hline Temnostoma balyras (Walker) & & & & 1 & \\
\hline Volucella bombylans (Linnaeus) & & & & 1 & \\
\hline Xylota quadrimaculata (Loew) & & & & & 1 \\
\hline Xylota confusa (Shannon) & & & & & 3 \\
\hline Number of individuals $\chi^{2}=45.9, P<0.001$ & 11 & 5 & 24 & 66 & 16 \\
\hline Standardized residuals, individuals (1998 data only) & & -3.7 & 2.0 & & 0.42 \\
\hline Number of species $\chi^{2}=5.5$, n.s. & 8 & 4 & 2 & 25 & 9 \\
\hline Standardized residuals, species (1998 data only) & & -1.3 & -0.4 & & 1.9 \\
\hline
\end{tabular}


syrphid individuals and species were captured in the Malaise trap set in the recently logged than in the wilderness habitat (Binomial test, species: $P<0.0001$, individuals: $P<0.0001)$. In 1998, using pan trap catches, two species, each consisting of one individual each, were found only in the wilderness zone, whereas nine species were found only in the recently logged landscape. Only six species were found in both years using the two capture techniques. Significantly more individuals were caught in 1998, in the old logged stands than in either the recently logged or wilderness treatments (Table 2), but this result was entirely due to a capture of 17 individuals of the species Melanostoma mellinum on 14 May 1998 in the old logged treatment.

In 1997, we did not begin sampling until late May, after leaf-out in the park. In 1998, there was a strong bias in the collection times for all syrphids, with 16 of 22 collection dates for syrphids (73\%) in May, prior to leaf-out. There was, however, no significant difference among treatments in the collection dates of syrphids in 1998 (median sample dates (range): wilderness: 29 May (26 May-6 August), $n=5$ trap sample dates; old logged: 21 May (14 May-2 July), $n=4$; recently logged: 27 May (9 May-24 June), $n=13$, Kruskal-Wallis $\left.\chi^{2}=4.33, P=0.11\right)$.

Bees. Twelve species of bees were identified, with five of these from wilderness and old logged stands and all twelve in the recently logged stands (Table 3). All but four species (excluding Andrena) were halictids. For both number of species and number of individuals the recently logged stands had significantly more bees than expected based on catch effort (Table 3 ).

All but 6 of the 57 dates on which we captured bees were in May. Bees were caught at a significantly later date in recently logged stands than in either old logged or wilderness stands (median collection dates (range): wilderness: 10 May (8-20 May), $n=18$ trap sample dates; old logged: 9 May (9 May-24 June), $n=13$; recently logged: 19 May (9 May-14 July), $n=26$, Kruskal-Wallis $\left.\chi^{2}=13.8, P<0.001\right)$.

Elateridae. In this group of insects, two species, Ctenicera triundulata and C. vulnerata were found only in the wilderness stands, both in very low numbers (Table 4). The number of species among treatments did not deviate from expected using the pan trap data but was marginally higher than expected in the old logged treatment using the combined $1997 / 1998$ pitfall data (combined years due to small sample sizes, $\chi^{2}=5.89$, $P<0.06)$.

Numbers of individual click beetles were significantly higher in the old logged habitat, and significantly lower in the wilderness zone than expected based on catch effort, using pan traps and pitfall traps (Table 4).

Elaterids were collected in 1998 from pan traps at significantly later dates in old logged and recently logged stands than in wilderness zone stands (median date (range); wilderness zone: 13 May (8 May-5 June), $n=9$; old logged: 28 May (8 May-9 July), $n=23$; recently logged: 19 May (9 May-2 July), $n=23$; Kruskal-Wallis $\chi^{2}=7.6, P=0.02$ ). Using 1998 pitfall data, elaterids were sampled significantly later in recently logged stands than in the other two treatments (wilderness zone: 17 May (13 May-4 August), $n=20$; old logged: 17 May (14 May-3 July, $n=22$; recently logged: 24 June (12 May-24 June), $n=9$; KruskalWallis $\left.\chi^{2}=6.34, P=0.04\right)$. The 1997 elaterid data were too sparse for analysis.

Spring ephemerals. We recorded 15 species of spring ephemerals in our quadrats (1998 only). The numbers of ephemerals found in all of the stands were extremely variable (cv's range from 156-165\%). Although the mean number of stems in the recently logged stands was more than twice as large as this number in wilderness zones, there was no significant difference among treatments (recently logged: $59.7 \pm$ $16.7 / \mathrm{m}^{2}, n=23$ plots; old logged: $46.5 \pm 22.1 / \mathrm{m}^{2}$, $n=13$ plots; wilderness zone: $26.5 \pm 18.8 / \mathrm{m}^{2}, n=18$ plots; $\mathrm{F}_{2,51}=0.88$, n.s.).

\section{Discussion}

Our results suggest that all three of groups of flowervisiting insects were more abundant in one of the logged habitat types than in the wilderness zone. This suggests that these insect groups were positively affected by single-tree selection harvesting as it is practised recently and/or how it was practised in the 1970s, when the selection cuts were heavier than is currently acceptable (Algonquin Forestry Authority, unpublished). This result is not explained simply by greater numbers of spring ephemerals, as, at least with our sampling methodology, we found no significant difference among treatments in the availability of flowers measured prior to leaf-out. Differences were apparent in number of individual insects, but, in general, not in insect species richness, except in the case of the Malaise traps set in 1997, where both numbers of individuals and species richness were higher in collections from the trap in the recently logged stand. Given that this result is for one trap only in each treatment, this result should be viewed cautiously.

As many larval syrphids prey on Homoptera in herbaceous vegetation and many adults feed on nectar sources in this vegetation, the presence of much higher percent cover of herbaceous or soft woody vegetation (37 to $43 \%$ in old logged and wilderness stands respectively, to $78 \%$ in recently logged stands, particularly Rubus idaeus L. var. strigosus (Michx), Jobes 1999) could explain the significant increase in syrphid abundance that we found through Malaise trapping. An apparent increase also was noted in our pan trapping results but not established statistically because of the generally poor success of this method for capturing syrphids in any of our stands. A similar positive numerical response in syrphids (also not tested statistically) was found in Poland's polluted spruce forests, 
TABLE 3. Species and Genera of bees collected from pan traps and numbers of individuals and minimum number of species, from Algonquin Park, summer 1998. 122 individuals captured. Statistics and standardized residuals as in Table 2.

\begin{tabular}{|c|c|c|c|}
\hline Genus & Wilderness & Old logged & Recent logged \\
\hline Andrena $^{1}$ & 36 & 20 & 21 \\
\hline Bombus perplexus Cresson & & 1 & 6 \\
\hline \multicolumn{4}{|l|}{ Bombus vagans Smith } \\
\hline Hylaeus elliptica (Kirby) & & & 1 \\
\hline Lasioglossum admirandus (Sandhouse) & 1 & & 9 \\
\hline Lasioglossum divergens (Lovell) & 1 & & 1 \\
\hline Lasioglossum laevissimus (Smith) & & 1 & 6 \\
\hline Lasioglossum nymphaearum (Robertson) & & & 1 \\
\hline Lasioglossum quebecensis (Crawford) & & & 1 \\
\hline Lasioglossum rohweri (Ellis) & & & 10 \\
\hline Lasioglossum versans (Lovell) & & 1 & 3 \\
\hline Lasioglossum zephyrus (Smith) & & & 1 \\
\hline Osmia atriventris Cresson & & & 1 \\
\hline Number of individuals $\chi^{2}=21.2, P<0.001$ & 38 & 23 & 61 \\
\hline Standardized residuals, individuals & -2.9 & 0.3 & 3.5 \\
\hline Minimum number of species $\chi^{2}=20.4, P<0.001$ & 3 & 4 & 12 \\
\hline Standardized residuals, species & -1.2 & 1.3 & 4.2 \\
\hline
\end{tabular}

${ }^{1}$ Not identified to species because of poor quality of specimens.

TABLE 4. Species and number of individuals of Elateridae collected from wilderness, old logged stands, and recently logged stands in Algonquin Park in 1997 and 1998 using pan traps (individuals: $\chi^{2}=175.1, P<0.00$; species: $\chi^{2}=3.2$, n.s.) and pitfall traps (individuals: $\chi^{2}=90.7, P<0.001$, species: $\chi^{2}=5.9$, n.s.). Analysis for pitfalls from two years combined). Standardized residuals as in Table 2 .

\begin{tabular}{|c|c|c|c|c|c|c|c|c|c|}
\hline \multirow[b]{2}{*}{ Species } & \multicolumn{3}{|c|}{ Wilderness } & \multicolumn{3}{|c|}{ Old logged } & \multicolumn{3}{|c|}{ Recent logged } \\
\hline & 98 Pan & 97 Pit & 98 Pit & $98 \mathrm{Pan}$ & 97 Pit & 98 Pit & 98 Pan & 97 Pit & 98 Pit \\
\hline Agriotes collaris (LeConte) & 2 & & 1 & 5 & & 6 & 1 & & 3 \\
\hline Agriotes stabilis (LeConte) & & & & & & 1 & & & \\
\hline Athous acanthus (Say) & & & & & 1 & & & & \\
\hline Ctenicera hieroglyphica (Say) ((Say)) & 1 & 2 & 2 & & & & & & 1 \\
\hline Ctenicera insidiosa (LeConte) & & & & & & & & 1 & \\
\hline Ctenicera resplendens (Eschscholtz) & & & 1 & & & 1 & & & \\
\hline Ctenicera spinosa (LeConte) & & & 1 & & & 1 & & & \\
\hline Ctenicera triundulata (Randall) & & 2 & & & & & & & \\
\hline Ctenicera vulnerata (LeConte) & 1 & & & & & & & & \\
\hline Dalopius cognatus Brown & & & & 1 & & & 1 & & \\
\hline Dalopius fuscipes Brown & & & 1 & & 1 & & & 1 & \\
\hline Dalopius spp. (females) & & & 2 & 2 & & 1 & 3 & & 2 \\
\hline Limonius aeger LeConte & & & & & & & 2 & & \\
\hline Limonius confusus LeConte & 5 & 1 & 1 & 4 & 1 & 2 & 9 & & 3 \\
\hline Melanotus castanipes (Paykull) (Paykull) & & & & & & & 1 & & \\
\hline Neohypdonus tumescens (LeConte) & & & 1 & & 1 & 2 & & & \\
\hline Selatosomus pulcher (LeConte) & 2 & & 10 & 59 & 2 & 28 & 10 & & \\
\hline Number of individuals & 11 & 5 & 20 & 71 & 6 & 42 & 27 & 2 & 9 \\
\hline Standardized residuals, individuals & -3.4 & -2 & & 11.8 & & 6 & -1.3 & -3 & \\
\hline Number of species & 5 & 3 & 9 & 5 & 5 & 8 & 7 & 2 & 4 \\
\hline Standardized residuals, species & -1.2 & -0 & & 1.1 & & .2 & 0.7 & -0 & \\
\hline
\end{tabular}

as an apparent result of drastic reductions in canopy cover and greater herbaceous and grass undergrowth (Kula 1997). Some species of at least two genera of hoverflies that were found in the wilderness zone (Melanostoma and Platycheirus) specialize on graminoid and other anemophilous pollen, enabling them to be active later into the spring/summer when grami- noids typically flower (Vockeroth 1992; Gilbert 1993). However, none of the species captured is restricted to flying in the spring.

Bees, like syrphids, were most abundant in the recently logged areas. Unlike syrphids, larval bees are fed pollen and thus are more wholly dependent on floral resources. Some bees also may be affected by the 
availability of open flight paths present in the open understory of the recently logged treatments, to make pollen-gathering trips for brood provisioning, although the effects of forest habitat on bee movement is probably species-specific, and for many species these movement patterns are unknown (Kreyer et al. 2004). Woodland and edge ground nesting bees (the majority of the species caught in the recently logged stands) are thought to benefit from patches of disturbed habitat associated with habitat fragmentation (Cane 1991) and thus, may benefit from the building of sand logging roads. Halictid bees can be major components of pollinator communities in other forest types (Pascarella 1997). Their role in northern hardwood forests has not been adequately assessed.

Elaterids were most abundant in the old logged habitats, using two methods of sampling, indicating positive responses to the much higher cover of the sapling $(2-10 \mathrm{~m})$ layers found in this treatment (Jobes et al. 2004). The most abundant species, Selatosomus pulcher, has been trapped in open field habitats (Boiteau et al. 2000). This species is morphologically nearly indistinguishable from the European species $C$. cruciatus, a species whose larvae develop in the sandy and moist soils in forest and forest edge (Leseigneur 1972). The higher abundance of elaterids in the old logged treatment areas may be due largely to this species' positive response to the edge-like conditions present in this treatment. The lower numbers of elaterids in the recently logged stands may indicate the absence of colonization because of the short time frame. Analagous results are suggested in a study of herbaceous plants in recently logged White Pine (Pinus strobus) stands in Algonquin. Plants in those stands were most similar to plants in unlogged stands presumably because there had been insufficient time for changes in community assemblages after the logging (Kingsley 1998).

As little is known about the role of adult food availability in the distribution of elaterids, the near significant positive effect on species richness may also be due to the greater availability of soil invertebrates or plant material suitable for larval food produced by a four-fold increase in the number of stumps in old logged versus either wilderness or recently logged stands (Jobes 1999).

Of the two elaterids caught only in the wilderness treatment, only one may be an old growth dependant species. Ctenicera vulnerata (1 specimen caught) has rarely been collected, and has not been reported previously from Ontario. The other, Ctenicera triundulata (2 specimens) cannot be considered old growth-restricted, as it has been collected in moderate numbers in an apparently healthy spruce (Picea sp.) in an old field by HD.

We found very few bees, syrphids or click beetles in our samples from the wilderness zone stands, although we expected to find some, at least early in the season when the canopy had not yet leafed out or of species that utilized downed woody debris (e.g., Chalcosyrphus, Xylota, Brachyopa). The reason for their paucity in the wilderness zone is unclear but deserves further study.

The numerical increase and changes in phenology of flower-associated insect species suggests the potential for greater pollinator efficiency in logged forests, and hence greater reproductive success, through greater seed set of flowers. A more detailed examination of species-specific patterns of habitat use by pollinators and their functional role in hardwood forests is worthy of future research (e.g., Sheffield et al. 2003; Kreyer et al. 2004).

\section{Acknowledgments}

We thank, in particular, Christine Vance, who tirelessly emptied pan traps in 1998 for this project. We also thank Andrew Jobes for collecting some of the data on spring ephemeral abundance and providing the canopy cover information. We thank E. C. Becker for verifying elaterid identifications, and R. Tuckerman, J. Grixti and T. Romankova for identification of bees. D. Voigt and E. Addison provided the stimulus for this project through their project on disturbance of ecosystems in Algonquin Park. We thank them for their extensive logistic support. The Algonquin Forestry Authority (AFA) also provided details on the history of the stands. N. Quinn (Algonquin Park) kindly provided funding for our work on birds and beetles in the park. This project was also funded by NSERC (Canada) grants to E. Nol.

\section{Literature Cited}

Annand, E. M., and F. R. Thompson III. 1997. Forest bird response to regeneration practices in central hardwood forest. Journal of Wildlife Management 61: 159-171.

Baars, M. 1979. Catches in pitfall densities in relation to mean densities of carabid beetles. Oecologia 41: 25-46.

Becker, E. C. 1956. Revision of the nearctic species of Agriotes (Coleoptera: Elateridae). Canadian Entomologist 88, Supplement 1. 101 pages.

Becker, E. C. 1974. Revision of the nearctic species of Athous (Coleoptera: Elateridae) east of the Rocky Mountains. Canadian Entomologist 106: 711-758.

Boiteau, G., W. P. L. Osborn, X. Xiong, and Y. Bousquet. 2000. The stability of vertical distribution profiles of insects in air layers near the ground. Canadian Journal of Zoology 78: 2167-2173.

Brown, W. J. 1934. The American species of Dalopius Esch. (Elateridae, Coleop.). Canadian Entomologist 66: 30-39, 66-72, 87-96, 102-110.

Cane, J. H. 1991. Soils of ground-nesting bees (Hymenoptera: Apoidea): texture, moisture, cell depth and climate. Journal of the Kansas Entomological Society 64: 406-413.

Coovert, G. A., and F. C. Thompson. 1977. The Sphegina species of eastern North America (Diptera: Syrphidae). Proceedings of the Biological Society of Washington 90: 536-552.

Curran, C. H. 1921. Revision of the Pipiza group of the family Syrphidae (flower-flies) from north of Mexico. Proceedings of the California Academy of Sciences, Fourth Series 11: 345-393. 
Curran, C. H. 1922. The syrphid genera Hammerschmidtia and Brachyopa in Canada. Annals of the Entomological Society of America 15: 239-255.

Curran, C. H. 1925. Revision of the genus Neoascia Williston (Diptera: Syrphidae). Proceedings of the Entomological Society of Washington 27: 51-62.

Curran, C. H. 1934. Notes on the Syrphidae in the Slosson collection of Diptera. American Museum Novitates (724).

Curran, C. H. 1941. New American Syrphidae. Bulletin of the American Museum of Natural History 78: 243-304.

Curran, C. H., and C. L. Fluke. 1926. Revision of the nearctic species of Helophilus and allied genera. Transactions of the Wisconsin Academy of Sciences, Arts and Letters 22: 207-281.

Dietrich, H. 1945. The Elateridae of New York State. Cornell University Agricultural Experimental Station Memoirs 269. 79 pages.

Fluke, C. L., and F. M. Hull. 1945. The Cartosyrphus flies of North America (Syrphidae). Transactions of the Wisconsin Academy of Sciences, Arts and Letters 37: 221-263.

Fluke, C. L., and H. V. Weems, Jr. 1956. The Myoleptini of the Americas (Diptera, Syrphidae). American Museum Novitates (1758)

Gilbert, F. S. 1993. Hoverflies. Naturalists' Handbooks S. Richmond Publishing Co. Ltd., Slough, England

Goulson, D., and N. P. Wright. 1998. Flower constancy in the hoverflies Episyrphus balteatus (Degeer) and Syrphus ribesii (L.) (Syrphidae). Behavioral Ecology 9: 213-219.

Gross, C. L. 2001. The effect of introduced honeybees on native bee visitation and fruit-set in Dillwynia juniperina (Fabaceae) in a fragmented ecosystem. Biological Conservation 102: 89-95.

Hull, F. M., and C. L. Fluke. 1950. The genus Cheilosia Meigen (Diptera, Syrphidae): The subgenera Cheilosia and Hiatomyia. Bulletin of the American Museum of Natural History 94: 303-401.

Hunter, M. L., Jr. 1990. Wildlife, forests, and forestry: principles of managing forests for biological diversity. Prentice-Hall, Englewood Cliffs, New Jersey.

Jobes, A. 1999. Effects of selection cutting on habitat structure and bird communities in the tolerant hardwood forests of Algonquiin Provincial Park, Ontario. B.Sc. thesis. Trent University, Peterborough, Ontario. 60 pages

Jobes, A. P., E. Nol, and D. R. Voigt. 2004. Effects of selection cutting on bird communities in contiguous eastern hardwood forests. Journal of Wildlife Management 68: 51-60.

Johnson P. J. 2002. Elateridae. Pages 160-173 in American Beetles. Volume 2. Edited by R. H. Arnett, M. C. Thomas, P. E. Skelley, and J. H. Frank. CRC Press LLC. Boca Raton, Florida.

Kingsley, A. L. 1998. Response of birds and vegetation to the first cut of the uniform shelterwood silvicultural system in the white pine forests of Algonquin Provincial Park, Ontario. Unpublished M.Sc. thesis, Trent University, Peterborough, Ontario. 110 pages.

Kreyer, D., A. Oed, K. Walther-Hellwig, and R. Frankl. 2004. Are forests potential landscape barriers for foraging bumblebees? Landscape scale experiments with Bom- bus terrestris agg. and Bombus pascuorum (Hymenoptera, Apidae). Biological Conservation 116: 111-119.

Kula, E. 1997. Hoverflies (Dipt.: Syrphidae) of spruce forest in different health condition. Entomophaga 42: 133-138.

Leseigneur, L. 1972. Coléoptères Elateridae de la Faune de France continentale et de Corse. Bulletin Mensuel de la Société Linnéenne de Lyon. Supplément. 379 pages.

Michener, C. D., R. M. McGinley, and B. N. Danforth. 1994. The bee genera of North and Central America (Hymenoptera: Apoidea). Smithsonian Institution, Washington. 209 pages.

Mitchell, T. B. 1960. Bees of the Eastern United States. Volume 1. North Carolina Agricultural Experiment Station, Raleigh, North Carolina.

Pascarella, J. B. 1997. Pollination ecology of Ardisia escallonioides (Myrsinaceae). Castanea 62: 1-7.

Penev, L. D. 1992. Qualitative and quantitative spatial variation in soil-wire-worm assemblages in relation to climatic and habitat factors. Oikos 63: 181-192.

Quinn, G. P., and M. J. Keough. 2002. Experimental design and data analysis for biologists. Cambridge University Press, Cambridge.

Shannon, R. C. 1939. Temnostoma bombylans and related species (Syrphidae, Diptera). Proceedings of the Entomological Society of Washington 41: 215-224.

Sheffield, C. S., P. G. Kevan, R. F. Smith, S. M. Rigby, and R. E. L. Rogers. 2003. Bee species of Nova Scotia, Canada, with new records and notes on bionomics and floral relations (Hymenoptera: Apoidea). Journal of the Kansas Entomological Society 76: 357-384.

Spence J. R., and J. K. Niemelä. 1994. Sampling carabid assemblages with pitfall traps: the madness and the method. Canadian Entomologist 126: 881-94.

Sugar, A., A. Finnamore, H. Goulet, J. Cumming, J. T. Kerr, and L. Packer. 1998. A preliminary survey of Symphytan and Aculeate Hymenoptera from oak savannahs in Southern Ontario. Proceedings of the Entomological Society of Ontario 129: 9-18.

Telford, H. S. 1970. Eristalis (Diptera: Syrphidae) from America north of Mexico. Annals of the Entomological Society of America 63: 1201-1210.

Vance, C., and E. Nol. 2003. Temporal effects of selection logging on ground beetle communities in northern hardwood forests of eastern Canada. Ecoscience 10: 49-56.

Vockeroth, J. R. 1992. The flower flies of the subfamily Syrphinae of Canada, Alaska, and Greenland. The Insects and Arachnids of Canada, Part 18. Research Branch, Agriculture Canada, Publication 1867.

Vockeroth, J. R., and F. C. Thompson. 1981. Syrphidae. Pages 713-743 in Manual of Nearctic Diptera, Volume 2. Edited by J. F. McAlpine, B. V. Peterson, G. E. Shewell, H. J. Teskey, J. R. Vockeroth, and D. M. Wood. Agriculture Canada, Research Branch Monograph (28).

Waldbauer, G. P. 1983. Flower associations of mimetic Syrphidae (Diptera) in northern Michigan. Great Lakes Entomologist 16: 79-85.

Received 14 July 2004

Accepted 7 February 2006 